\title{
Characteristics of SARS-CoV-2 aerosol dispersion in indoor air: scoping review
}

\author{
Características da dispersão de aerossóis com SARS-CoV-2 em locais fechados: scoping review \\ Características de la dispersión de aerosol con SARS-CoV-2 en ubicaciones cerradas: scoping \\ review
}

Received: 03/26/2021 | Reviewed: 04/04/2021 |Accept: 04/08/2021 | Published: 04/17/2021

\author{
Anyele Albuquerque Lima \\ ORCID: https://orcid.org/0000-0001-7254-9412 \\ Federal University of Alagoas, Brazil \\ E-mail: anyele_lima@hotmail.com \\ Izabelly Carollynny Maciel Nunes \\ ORCID: https://orcid.org/0000-0002-5032-2759 \\ Federal University of Alagoas, Brazil \\ E-mail: izabelly.nuness@gmail.com \\ José Leandro da Silva Duarte \\ ORCID: https://orcid.org/0000-0001-5641-0648 \\ Federal University of Alagoas, Brazil \\ E-mail: leandrosduarte@yahoo.com.br \\ Lucas Meili \\ ORCID: https://orcid.org/0000-0002-0307-8204 \\ Federal University of Alagoas, Brazil \\ E-mail: lucas.meili@ctec.ufal.br \\ Patricia de Carvalho Nagliate \\ ORCID: https://orcid.org/0000-0001-6715-0028 \\ Federal University of Alagoas, Brazil \\ E-mail: patrícia.nagliate@eenf.ufal.br \\ Alda Graciele Claudio dos Santos Almeida \\ ORCID: https://orcid.org/0000-0003-0406-8849 \\ Federal University of Alagoas, Brazil \\ E-mail: alda.almeida@esenfar.ufal.br
}

\begin{abstract}
Background: SARS-CoV-2 is the infectious agent responsible for COVID-19, its transmission occurs through the release of respiratory droplets and aerosols. Aim: Identify the main characteristics of SARS-CoV-2 aerosols dispersion in indoor air. Methods: Scoping Review was conducted using the databases: National Library of Medicines - MEDLINE/Pubmed, Scopus, Web of Science, Virtual Health Library (VHL) and Cochrane Library, the search in gray literature was performed on Google Scholar, OpenGrey and Grey Literature Report, from March to September 2020. The descriptors used were "coronavirus" and "aerosol". Data were selected and screened following the protocol established by the The Joanna Briggs Institute, PRISMA flow diagram and EndNote reference management tool. Findings: Ten papers were selected, which presented characteristics that could influence the SARS-CoV-2 aerosols dispersion, with highlight to: aerosol origin; viral load identified in the air (2.86 copies/liter of air); aerosol particle size with viral load $(0.25 \mu \mathrm{m})$; dispersion $(10.00 \mathrm{~m})$; air stay time $(3 \mathrm{~h})$; influence of air temperature and relative humidity. Conclusion: Aerosol particles containing SARS-CoV-2 may have infectious viral charge, presenting a minimum size up to $0.25 \mu \mathrm{m}$, being able to reach up to $10 \mathrm{~m}$ of distance and survive in the air for a few hours. The variables air temperature and relative humidity did not present consistent evidence to influence the dispersion of SARS-CoV-2 aerosols.
\end{abstract}

Keywords: Coronavirus; Dissemination; COVID-19; Airborne.

\section{Resumo}

Introdução: SARS-CoV-2 é o agente infeccioso responsável pela COVID-19, sua transmissão ocorre por meio da liberação de gotículas. Entretanto, a disseminação via aerossóis é descrita na literatura como uma das formas possíveis de transmissão do SARS-CoV-2. Objetivo: Identificar as principais características de dispersão dos aerossóis com SARS-CoV-2 no ar. Métodos: Scoping Review realizada nas bases de dados: National Library of Medicines MEDLINE/via Pubmed, Scopus, Web of Science, Biblioteca Virtual de Saúde (BVS) e Cochrane Library, a busca na literatura cinzenta foi realizada no Google Scholar, OpenGrey e Grey Literature Report, durante Março a Maio de 2020. Utilizou-se os descritores: "coronavirus" and "aerosol". A seleção e triagem dos dados foram feitos seguindo as orientações do protocolo PRISMA flow diagram e a ferramenta de gerenciamento de referências EndNote. Resultados: Selecionaram-se 10 artigos, os quais continham características que poderiam influenciar na dispersão de aerossóis contendo o SARS-CoV-2, dentre elas as que se destacaram foram: origem do aerossol; carga viral identificada no ar 
(2.86 cópias/litro de ar); tamanho da partícula de aerossol com carga viral $(0.25 \mu \mathrm{m})$; dispersão $(10 \mathrm{~m})$; tempo de permanência no ar (3 h); influência da temperatura e da umidade relativa do ar. Conclusão: As partículas de aerossóis com SARS-CoV-2 podem possuir uma carga viral infecciosa, apresentando um tamanho mínimo de até $0,25 \mu \mathrm{m}$, sendo capaz de alcançar até $10 \mathrm{~m}$ de distância e sobreviver no ar por algumas horas. As variáveis temperatura e umidade relativa do ar não apresentaram evidências consistentes que comprovem influenciar na dispersão dos aerossóis com SARS-CoV-2.

Palavras-chave: Coronavírus; Dispersão; SARS-CoV-2; Aerossol.

\section{Resumen}

Introducción: El SARS-CoV-2 es el agente infeccioso responsable del COVID-19, su transmisión ocurre a través de la liberación de gotitas. Sin embargo, la propagación a través de aerosoles se describe en la literatura como una de las posibles formas de transmisión del SARS-CoV-2. Objetivo: Identificar las principales características de dispersión de aerosoles con SARS-CoV-2 en el aire. Métodos: Scoping Review realizada en las bases de datos: National Library of Medicines - MEDLINE / vía Pubmed, Scopus, Web of Science, Virtual Health Library (VHL) y Cochrane Library, la búsqueda de literatura gris se realizó en Google Scholar, OpenGrey y Grey Literature Informe, durante marzo a mayo de 2020. Se utilizaron los descriptores: "coronavirus" y "aerosol". La selección y ordenación de los datos se realizó siguiendo las pautas del protocolo de diagrama PRISMA flow y la herramienta de gestión de referencias EndNote. Resultados: Se seleccionaron 10 artículos, los cuales contenían características que pudieran influir en la dispersión de aerosoles conteniendo SARS-CoV-2, entre los que se destacaron: origen del aerosol; carga viral identificada en el aire ( 2,86 copias / litro de aire); tamaño de partícula de aerosol con carga viral $(0,25 \mu \mathrm{m})$; dispersión (10 m); tiempo en el aire (3 h); influencia de la temperatura y la humedad relativa. Conclusión: Las partículas de aerosol con SARS-CoV-2 pueden tener una carga viral infecciosa, presentando un tamaño mínimo de hasta $0,25 \mu \mathrm{m}$, pudiendo llegar hasta $10 \mathrm{~m}$ y sobrevivir en el aire durante unas horas. Las variables temperatura y humedad relativa del aire no presentaron evidencias consistentes que prueben influir en la dispersión de los aerosoles con SARS-CoV-2.

Palabras clave: Coronavirus; Dispersión; COVID-19; Aerosol.

\section{Introduction}

SARS-CoV-2 (Coronavirus related to Severe Acute Respiratory Syndrome 2) is the infectious agent responsible for coronavirus disease 2019 (COVID-19)(World Health Organization, 2020e). The new coronavirus can cause infections in both the upper and lower respiratory tract (Chen, 2020). Individuals infected with the virus may be asymptomatic or have various mild or severe symptoms, cough, and respiratory failure, respectively. Its transmission occurs mainly through the release of respiratory droplets $(>5.00 \mu \mathrm{m})$ produced when an infected person coughs, sneezes or speaks (Centers for disease control and prevention, 2020a; World Health Organization, 2020d, 2020a). In addition, transmission can also occur during the performance of care procedures with the capacity to generate aerosols or by contact with contaminated fomites, configuring a contamination profile by direct or indirect contact (Peng et al., 2020; World Health Organization, 2020c).

From this perspective, one of the recommendations to prevent infection is to maintain $1.00 \mathrm{~m}$ of distance between people (World Health Organization, 2020b). However, the dissemination by aerosols $(<5.00 \mu \mathrm{m})$ is described in the literature as one of the possible forms of SARS-CoV-2 transmission (Asadi, Bouvier, Wexler, \& Ristenpart, 2020; Morawska \& Cao, 2020; World Health Organization, 2020d). Due to the smaller size, these particles can remain suspended in the air for hours and reach distances greater than $1.00 \mathrm{~m}$ (Asadi et al., 2020). Nevertheless, WHO states that transmission by aerosols may be possible only in circumstances when aerosol-generating procedures are performed, such as endotracheal intubation, bronchoscopy, aspiration, and nebulization (World Health Organization, 2020d).

Therefore, this study is justified by the need to understand the characteristics of the dispersion of the new coronavirus via aerosol, considering the origin of the coronavirus, such as coughing, sneezing, speech or care procedures, the distance traveled, the time of permanence in the environment, among others. Understanding the behavior of infectious aerosol is an important theoretical component for the adoption of appropriate preventive. Thereby, the aim of this study was to identify the main characteristics of SARS-CoV-2 aerosols dispersion in indoor air using the Scoping Review methodology. 


\section{Methodology}

This is a Scoping Review, based on the protocol established by the The Joanna Briggs Institute Reviewers' Manual (Peters et al., 2020). Each step performed in the methodology was performed by two researchers independently.

\subsection{Search strategy}

For the search strategy design, the research question was first constructed using the PCC elements acromion for the scoping review, in which $\mathrm{P}=$ Population, $\mathrm{C}=\mathrm{Concept}$ and $\mathrm{C}=$ Context (Peters et al., 2020). Then: $\mathrm{P}=\mathrm{SARS}-\mathrm{CoV}-2$; $\mathrm{C}=$ Dispersion characteristics of aerosols in air and $\mathrm{C}=$ indoor environment. Based on these definitions, the guiding question was established: What are the characteristics of SARS-CoV-2 aerosols dispersion in indoor air?

Based on the guiding question, the search was configured in three stages: validation of the search strategy; search in all databases and in the gray literature; and conducting the search in the paper theoretical references. The search strategy was also inspired by the PRESS (Peer Review of Electronic Search Strategies) protocol (McGowan et al., 2016).

In the first stage, the search strategy was validated in two databases, MEDLINE and Web of Science. It was verified which strategy configuration was more effective considering the most relevant data and consistency with the guiding question. The combinations of the terms coronavirus, dispersion and aerosol were tested with Boolean operators: coronavirus AND dispersion OR disperse AND aerosol OR airborne; coronavirus AND dispersion OR disperse; coronavirus AND aerosol OR airborne; coronavirus AND aerosol.

Next, it was observed that the coronavirus AND aerosol configuration proved to be the best crossing for study recovery that answered the guiding question and with lower loss of articles. The "year 2020" filter was used to delimit only studies on the new coronavirus.

In the second stage, the primary search was performed in the Scopus, National Library of Medicines (NLM) - MEDLINE databases via PubMed, Web of Science, Cochrane Library and Virtual Health Library (VHL). The search in the gray literature was performed in Google Scholar, OpenGrey and Grey Literature Report. The descriptors used were coronavirus and aerosol according to the Descriptors in Health Sciences (DECS) via VHL and Medical Subject Headings (MeSH) via PubMed. Then, the theoretical references from the founded papers were searched. This third stage was characterized by reading the titles of the cited studies in the references from the papers that was fully analyzed. This stage followed the same rigor and screening process of the primary search.

Data were collected from March 1, 2020 to September 30, 2020. To attribute veracity and consistency to the study, the recommendations of the Statement for Reporting Systematic Reviews and Meta-Analyses of Studies - PRISMA were used as a theoretical reference for the formulation of data screening (PRISMA, 2015). EndNote software was used for reference management.

\subsection{Selection criteria}

As inclusion criteria: original articles available in full, online, with diverse methodological approaches, in all languages, published between January 1, 2020 and May 2020, and that answered the guiding question. Exclusion criteria were articles without free access; editorials; books; letters to the editor of an opinionated nature, without methodological and scientific basis.

\subsection{Extraction, analysis and results presentation}

Data extraction was performed using a structured framework with all the necessary information to answer the research question. To enhance the synthesis and presentation of the data, two tables were constructed with the needed characteristics for 
the analysis. The first table had variables previously defined by the authors: title; authors; year; country of publication; objective (s); study design; main findings and conclusions. This table served for the general evaluation and verification of the main findings.

The main characteristics of SARS-CoV-2 aerosol dispersion comprised the second table: aerosol origin; viral load identified in the air; aerosol particle size with viral load; dispersion; time of stay in the air; influence of air temperature and relative humidity.

\section{Results}

A total of 3.061 articles were found, 327 duplicated were excluded, resulting in 2706 papers. From these, 2.675 were excluded after reading the titles and abstracts since they did not fit the proposed theme, resulting in 31 articles. These were selected for full reading and 21 were excluded while did not answer the guiding question or the eligibility criteria; 10 articles remained as the final sample to compose the review, as shown in the PRISMA flowchart (Figure 1). Observing the flowchart is possible to understand all the papers selection strategy.

All included articles are written in English. The presence of five review articles stands out (A4, A5, A6, A7, A9), of these, three (A5, A7 and A9) were literature review studies; one (A6) systematic review and one (A4) narrative review. The other studies were divided into experimental methodological design (A1, A2, A8 and A10) and one exploratory study (A3) with a quantitative approach. The prevalence of review articles and exploratory studies is highlighted. Table 1 presents the results of this research through the data synthesis from each study. The following variables are presented: title of the article; authors; publication year; publication country; aim; study design and main results/conclusions.

It was identified that the majority (six) of the articles (A2, A4, A5, A6, A7 and A8) presented as objective to verify the transmission of SARS-CoV-2 in order to elucidate its aerodynamic characteristics, transmission routes, as well as social distancing based on aerosol particle dispersion. The most pertinent characteristics of aerosols with coronavirus can be observed in Table 2. In this table the aerosol origin, viral load identified in the air, aerosol particle size with viral load, dispersion, time of stay in the air, influence of temperature and relative humidity are considered and disposed. The variable aerosol origin was analyzed in two perspectives, such as, origin referring to the samples used in quantitative and exploratory studies and referring to the physiological origin.

Of the 10 articles analyzed, it was found that most (seven) of the studies (A3, A4, A5, A6, A7, A8 and A9) used samples of aerosols from cough, speech, sneezing, dyspneic breathing, during aerosol-producing procedures (laryngoscopy and bronchoscopy) and noninvasive ventilation (oxygen mask, nasal cannula); while, three studies (A2, A3 and A10) used air samples from the hospital environment (rooms and corridors; wards), as well as particles in air borne (ICU and deposited in the environment); only one study (A1) used a laboratory sample generated by an artificial disperser (nebulizer).

The viral load present in aerosol particles ranged from 0.3 to 2.86 copies per liter of air, 18 to 113 copies m- $2 \mathrm{~h}-1,10$ TCID per liter of air, and the mean concentrations varied. The particle size of the aerosols was less than or equal to $5 \mu \mathrm{m}$. In relation to the dispersion of aerosol particles, the dissemination was up to $10.0 \mathrm{~m}$. The length of stay of the aerosol with viable viral load for transmission and infection was three hours. 
Figure 1. PRISMA flow diagram.

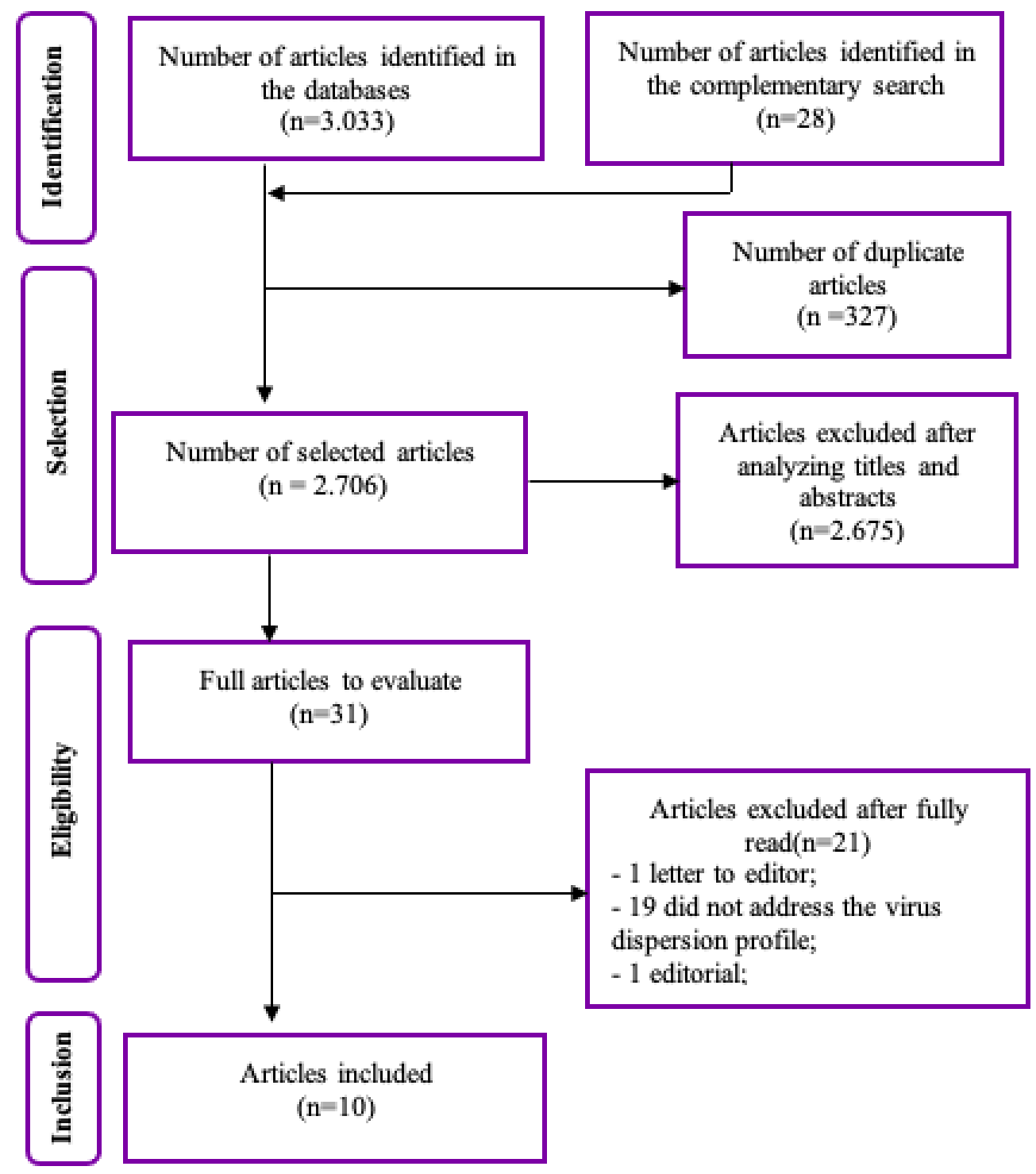

Source: Authors. 
Table 1. General description of the selected articles and presentation of the main findings and conclusions, 2020.

\begin{tabular}{|c|c|c|c|c|c|c|c|c|}
\hline & Title & Authors & Year & Country & Aims & Study desing & Main results & Main conclusions \\
\hline Article 1 & $\begin{array}{l}\text { Aerosol and } \\
\text { Surface } \\
\text { Stability of } \\
\text { SARS-CoV-2 } \\
\text { as Compared } \\
\text { with SARS- } \\
\text { CoV-1 }\end{array}$ & $\begin{array}{l}\text { Doremalen NV, } \\
\text { Bushmaker T, } \\
\text { Morris DH, } \\
\text { Holbrook MG, } \\
\text { Gamble A, } \\
\text { Williamson BN, } \\
\text { et al. (Doremalen } \\
\text { et al., 2020) }\end{array}$ & $\begin{array}{c}202 \\
0\end{array}$ & USA & $\begin{array}{l}\text { Assess the stability of } \\
\text { SARS-CoV- } 2 \text { and } \\
\text { SARS-CoV-1 in } \\
\text { aerosols and on } \\
\text { various surfaces, also } \\
\text { estimate their decay } \\
\text { rates }\end{array}$ & $\begin{array}{c}\text { Experimental study: } \\
\text { Aerosol particles }(<5 \\
\mu \mathrm{m}) \text { containing SARS- } \\
\text { CoV-2 }\left(10^{5.25} 50 \%\right. \\
\text { infectious dose of tissue } \\
\text { culture }\left[\mathrm{TCID}_{50}\right] \text { per } \\
\text { milliliter) were } \\
\text { generated using a } \\
\text { nebulizer. }\end{array}$ & $\begin{array}{l}\text { The results showed that SARS-CoV- } \\
2 \text { remains viable in aerosols for } 3 \\
\text { hours, with an infectious titer of } \\
10^{2.7} \mathrm{TCID}_{50} \text { per liter of air. }\end{array}$ & $\begin{array}{l}\text { They indicated that the } \\
\text { aerosol transmission of } \\
\text { SARS-CoV-2 is plausible } \\
\text { since the virus can } \\
\text { remain viable and } \\
\text { infectious in aerosols for } \\
\text { hours. }\end{array}$ \\
\hline Article 2 & $\begin{array}{l}\text { Aerodynamic } \\
\text { Characteristics } \\
\text { and RNA } \\
\text { Concentration } \\
\text { of SARS-CoV-2 } \\
\text { Aerosol in } \\
\text { Wuhan } \\
\text { Hospitals } \\
\text { during COVID- } \\
19 \text { Outbreak }\end{array}$ & $\begin{array}{l}\text { Liu Y, Ning Z, } \\
\text { Chen Y, Guo M, } \\
\text { Liu Y, Gali NK, et } \\
\text { al. (Liu et al., } \\
\text { 2020) }\end{array}$ & $\begin{array}{c}202 \\
0\end{array}$ & China & $\begin{array}{l}\text { Investigate the } \\
\text { concentration and } \\
\text { aerodynamic } \\
\text { characteristics of the } \\
\text { SARS-CoV-2 airborne } \\
\text { aerosol in different } \\
\text { areas of two hospitals } \\
\text { in Wuhan }\end{array}$ & $\begin{array}{c}\text { Quantitative } \\
\text { experimental study: } 35 \\
\text { aerosol samples of } 3 \\
\text { different types (total } \\
\text { suspended particle, } \\
\text { segregated size and } \\
\text { deposition aerosol) } \\
\text { were collected at two } \\
\text { hospitals in Wuhan, } \\
\text { China }\end{array}$ & $\begin{array}{l}\text { Regarding the concentrations of } \\
\text { SARS-CoV- } 2 \text { in the air, the study } \\
\text { found in: Patient mobile toilet } \\
\text { room: } 19 \text { copies } / \mathrm{m}^{-3} \text {; Male staff } \\
\text { change room: } 20 \text { copies } / \mathrm{m}^{3} \text {; } \\
\text { Warehouse: } 21 \text { copies } / \mathrm{m}^{3} \text { e ICUs: } \\
113 \text { copies } / \mathrm{m}^{3} \text {. The maximum } \\
\text { concentration of SARS-CoV- } 2 \text { in } \\
\text { aerosols appears between the } \\
\text { ranges of } 0.25 \text { to } 2.5 \mu \mathrm{m} \text {. While the } \\
\text { highest rate of aerosol deposition } \\
\text { with the virus was found in the ICU } \\
\left(113 \text { copies } \mathrm{m}^{-2} \text { hour }{ }^{-1} \text {. }\right.\end{array}$ & $\begin{array}{l}\text { The proper use and } \\
\text { cleaning of bathrooms } \\
\text { was recommended, as } \\
\text { they can act as a } \\
\text { potential source of } \\
\text { dissemination of the } \\
\text { coronavirus with } \\
\text { relatively high risk } \\
\text { caused by aerosolization } \\
\text { of the virus and } \\
\text { contamination of } \\
\text { surfaces after use. }\end{array}$ \\
\hline Article 3 & $\begin{array}{l}\text { Transmission } \\
\text { Potential of } \\
\text { SARS-CoV-2 in } \\
\text { Viral Shedding } \\
\text { Observed at } \\
\text { the University } \\
\text { of Nebraska } \\
\text { Medical Center }\end{array}$ & $\begin{array}{l}\text { Santarpia JL, } \\
\text { Rivera DN, } \\
\text { Herrera V, } \\
\text { Morwitzer MJ, } \\
\text { Creager H, } \\
\text { Santarpia GW, et } \\
\text { al. (Santarpia et } \\
\text { al., 2020) }\end{array}$ & $\begin{array}{c}202 \\
0\end{array}$ & USA & $\begin{array}{l}\text { Obtain surface and air } \\
\text { samples from } 2 \\
\text { hospitals in the } \\
\text { United States to } \\
\text { improve } \\
\text { understanding of the } \\
\text { potential } \\
\text { environmental } \\
\text { transmission risk of }\end{array}$ & $\begin{array}{l}\text { Continuous exploratory } \\
\text { quantitative study: } \\
11 \text { air and surface } \\
\text { samples }\end{array}$ & $\begin{array}{l}\text { The ambient air samples in the } \\
\text { rooms were } 63.2 \% \text { positive } \\
\text { (average concentration } 2.86 \text { copies } \\
\text { / liter of air). Those obtained in the } \\
\text { corridors were } 66.7 \% \text { positive } \\
\text { (average concentration of } 2.59 \\
\text { copies / liter of air). }\end{array}$ & $\begin{array}{l}\text { They revealed that when } \\
\text { analyzing air samples } \\
\text { taken both in the rooms } \\
\text { and in the corridor } \\
\text { spaces, they indicated } \\
\text { positive spread of the } \\
\text { virus in the air. }\end{array}$ \\
\hline
\end{tabular}




\begin{tabular}{|c|c|c|c|c|c|c|c|c|}
\hline & & & & & $\begin{array}{l}\text { SARS-CoV-2, refine } \\
\text { infection prevention } \\
\text { and control practices } \\
\text { and protocols, and } \\
\text { inform broader } \\
\text { outbreak control } \\
\text { strategies }\end{array}$ & & & \\
\hline Article 4 & $\begin{array}{l}\text { Airborne } \\
\text { transmission of } \\
\text { severe acute } \\
\text { respiratory } \\
\text { syndrome } \\
\text { coronavirus-2 } \\
\text { to healthcare } \\
\text { workers: a } \\
\text { narrative } \\
\text { review }\end{array}$ & $\begin{array}{l}\text { Wilson NM, } \\
\text { Norton A, Young } \\
\text { FP, Collins DW. } \\
\text { (Wilson, Norton, } \\
\text { Young, \& Collins, } \\
\text { 2020) }\end{array}$ & $\begin{array}{c}202 \\
0\end{array}$ & UK & $\begin{array}{l}\text { Explain the } \\
\text { characteristics of } \\
\text { aerosol viral } \\
\text { transmission, } \\
\text { speculating the } \\
\text { correlation of this } \\
\text { transmission with } \\
\text { that of the } \\
\text { coronavirus for health } \\
\text { professionals }\end{array}$ & Narrative Review & $\begin{array}{l}\text { It was emphasized that the } \\
\text { coronavirus remains stable and } \\
\text { infectious in artificially generated } \\
\text { aerosols }(<5 \mu \mathrm{m}) \text { for up to } 3 \text { hours. } \\
\text { And that the SARS-Cov- } 2 \text { RNA can } \\
\text { be found in aerosol particles in the } \\
\text { submicrometric range }(0.25-1 \mu \mathrm{m}) \text {. }\end{array}$ & $\begin{array}{l}\text { They speculated that the } \\
\text { respiratory } \\
\text { pathophysiology of the } \\
\text { coronavirus could } \\
\text { increase the exhaled } \\
\text { infectious particles. } \\
\text { These particles can gain } \\
\text { direct access to } \\
\text { angiotensin 2-converting } \\
\text { enzyme (ACE 2) } \\
\text { receptors on the alveolar } \\
\text { surface and transmit the } \\
\text { infection to the lung } \\
\text { under appropriate } \\
\text { physical, environmental, } \\
\text { and biological conditions. }\end{array}$ \\
\hline Article 5 & $\begin{array}{l}\text { Airborne } \\
\text { Transmission } \\
\text { Route of } \\
\text { COVID-19: } \\
\text { Why } 2 \\
\text { Meters/6 Feet } \\
\text { of Inter- } \\
\text { Personal }\end{array}$ & $\begin{array}{c}\text { Setti L, Passarini } \\
\text { F, De Gennaro G, } \\
\text { Barbieri P, } \\
\text { Perrone MG, } \\
\text { Borelli M, et al. } \\
\text { (Setti et al., } \\
\text { 2020) }\end{array}$ & $\begin{array}{c}202 \\
0\end{array}$ & Italy & $\begin{array}{l}\text { Draw the possible } \\
\text { transmission routes } \\
\text { for COVID-19 and the } \\
\text { distance considered } \\
\text { safe to prevent the } \\
\text { spread of the virus } \\
\text { between individuals }\end{array}$ & Literature review & $\begin{array}{l}\text { Scientific evidence on the } \\
\text { association between the levels of } \\
\text { particulate matter and the spread } \\
\text { of SARS-CoV- } 2 \text { in the air indicates } \\
\text { that distances between people up } \\
\text { to } 10 \text { meters should be adopted } \\
\text { indoors when masks are not used. } \\
\text { In the case of wearing masks, the } \\
\text { distance between people can be } 2 \\
\text { meters. }\end{array}$ & $\begin{array}{l}\text { They conclude that, the } \\
\text { information available on } \\
\text { the worldwide } \\
\text { dissemination of SARS- } \\
\text { VOC- } 2 \text { supports the } \\
\text { hypothesis of a } \\
\text { transmission of } \\
\text { particulate material }\end{array}$ \\
\hline
\end{tabular}


Research, Society and Development, v. 10, n. 4, e44310414300, 2021

(CC BY 4.0) | ISSN 2525-3409 | DOI: http://dx.doi.org/10.33448/rsd-v10i4.14300

\begin{tabular}{|c|c|c|c|c|c|c|c|c|}
\hline & $\begin{array}{l}\text { Distance Could } \\
\text { Not Be Enough }\end{array}$ & & & & & & & $\begin{array}{l}\text { through the air over } \\
\text { more than two meters. }\end{array}$ \\
\hline Article 6 & $\begin{array}{l}\text { Airborne or } \\
\text { Droplet } \\
\text { Precautions for } \\
\text { Health } \\
\text { Workers } \\
\text { Treating } \\
\text { Coronavirus } \\
\text { Disease 2019? }\end{array}$ & $\begin{array}{c}\text { Bahl P, Doolan C, } \\
\text { de Silva C, } \\
\text { Chughtai AA, } \\
\text { Bourouiba L, } \\
\text { Maclntyre CR. } \\
\text { (Bahl et al., } \\
\text { 2020) }\end{array}$ & $\begin{array}{c}202 \\
0\end{array}$ & USA & $\begin{array}{l}\text { Review the evidence } \\
\text { supporting the } 1 \\
\text { meter ( } \approx 3 \text { feet) } \\
\text { spatial separation } \\
\text { rule for droplet } \\
\text { precautions in the } \\
\text { context of guidelines } \\
\text { issued by WHO, CDC } \\
\text { and European Center } \\
\text { for Disease } \\
\text { Prevention and } \\
\text { Control (ECDC) for } \\
\text { healthcare } \\
\text { professionals in } \\
\text { respiratory protection } \\
\text { of COVID-19 }\end{array}$ & Systematic review & $\begin{array}{l}\text { They point out that the virus can } \\
\text { remain viable in air in aerosol } \\
\text { particles for up to } 3 \text { hours. While } \\
\text { the results for the appropriate } \\
\text { distance range from } 1.4 \text { meters } \\
(\approx 4.5 \text { feet) to } 8 \text { meters ( } \approx 26 \text { feet). }\end{array}$ & $\begin{array}{l}\text { They reveal that scientific } \\
\text { data is limited to inform } \\
\text { spatial separation } \\
\text { guidelines, and that } \\
\text { there is much evidence } \\
\text { that droplet precautions } \\
\text { are not appropriate for } \\
\text { SARS-CoV-2. }\end{array}$ \\
\hline Article 7 & $\begin{array}{l}\text { Consideration } \\
\text { of the Aerosol } \\
\text { Transmission } \\
\text { for COVID-19 } \\
\text { and Public } \\
\text { Health }\end{array}$ & $\begin{array}{l}\text { Anderson EL, } \\
\text { Turnham P, } \\
\text { Griffin JR, Clarke } \\
\text { CC. (Anderson, } \\
\text { Turnham, Griffin, } \\
\text { \& Clarke, 2020) }\end{array}$ & $\begin{array}{c}202 \\
0\end{array}$ & USA & $\begin{array}{l}\text { Focus on the limited } \\
\text { evidence available to } \\
\text { deal with airborne } \\
\text { SARS-CoV-2 } \\
\text { transmission }\end{array}$ & Literature review & $\begin{array}{l}\text { They approached that aerosolized } \\
\text { SARS-CoV- } 2 \text { particles remain } \\
\text { suspended in the air for hours ( } 3 \mathrm{~h} \text { ). } \\
\text { And that case reports of } \\
\text { coronavirus infection and studies } \\
\text { show that normal breathing and } \\
\text { speech produce small droplets in } \\
\text { the }<1 \mu \mathrm{m} \text { size range, subject to } \\
\text { aerosol transport. }\end{array}$ & $\begin{array}{l}\text { They indicate that the } \\
\text { literature reports limited } \\
\text { information on the } \\
\text { aerosol transport of } \\
\text { SARS-CoV-2, stating that } \\
\text { the broader literature } \\
\text { addresses that aerosol } \\
\text { transmission of } \\
\text { infectious diseases is } \\
\text { influenced by time and } \\
\text { distances of survival, } \\
\text { concentrations of the } \\
\text { infectious agent, by } \\
\text { effects of temperature } \\
\text { and humidity. }\end{array}$ \\
\hline
\end{tabular}




\begin{tabular}{|c|c|c|c|c|c|c|c|c|}
\hline Article 8 & $\begin{array}{l}\text { Respiratory } \\
\text { virus shedding } \\
\text { in exhaled } \\
\text { breath and } \\
\text { efficacy of face } \\
\text { masks }\end{array}$ & $\begin{array}{l}\text { Leung NHL, Chu } \\
\text { DKW, Shiu EYC, } \\
\text { Chan KH, } \\
\text { McDevitt JJ, Hau } \\
\text { BJP, et al. (Leung } \\
\text { et al., 2020) }\end{array}$ & $\begin{array}{c}202 \\
0\end{array}$ & China & $\begin{array}{l}\text { Explore the } \\
\text { importance of } \\
\text { respiratory droplet } \\
\text { and aerosol } \\
\text { transmission routes, } \\
\text { focusing on } \\
\text { coronavirus, influenza } \\
\text { and rhinovirus, } \\
\text { quantifying the viral } \\
\text { particles found in the } \\
\text { expiration of } \\
\text { participants with viral } \\
\text { respiratory disease } \\
\text { treated clinically and } \\
\text { determining the } \\
\text { potential } \\
\text { effectiveness of } \\
\text { surgical masks to } \\
\text { prevent transmission } \\
\text { of the virus }\end{array}$ & $\begin{array}{c}\text { Experimental } \\
\text { quantitative study }\end{array}$ & $\begin{array}{l}\text { The viral ARN responsible for the } \\
\text { coronavirus was identified only } \\
\text { from respiratory droplets and } \\
\text { aerosols in individuals who did not } \\
\text { use masks, with the proportion of } \\
\text { positive results for droplets } 3 \text { in } 10 \\
\text { individuals, and aerosol particles } 4 \\
\text { in } 10 \text { individuals, with the average } \\
\text { viral load of } 0.3 \text { for both particles. }\end{array}$ & $\begin{array}{l}\text { They have shown that } \\
\text { surgical masks are } \\
\text { effective in reducing the } \\
\text { detection of } \\
\text { coronaviruses and viral } \\
\text { copies in large } \\
\text { respiratory droplets and } \\
\text { aerosols. Therefore, the } \\
\text { study indicates that there } \\
\text { may be considerable } \\
\text { heterogeneity in the } \\
\text { contagiousness of } \\
\text { individuals with } \\
\text { coronavirus infections. }\end{array}$ \\
\hline Article 9 & $\begin{array}{l}\text { Protection and } \\
\text { disinfection } \\
\text { policies against } \\
\text { SARS-CoV-2 } \\
\text { (COVID-19) }\end{array}$ & $\begin{array}{c}\text { Fathizadeh H, } \\
\text { Maroufi P, } \\
\text { Momen-Heravi } \\
\text { M, Dao S, Köse S, } \\
\text { Ganbarov K, et } \\
\text { al. (Fathizadeh et } \\
\text { al., 2020) }\end{array}$ & $\begin{array}{c}202 \\
0\end{array}$ & Italy & $\begin{array}{l}\text { Summarize and } \\
\text { review the latest } \\
\text { findings on the } \\
\text { persistence of SARS- } \\
\text { CoV-2 outside the } \\
\text { body and strategies } \\
\text { to prevent its spread }\end{array}$ & Literature review & $\begin{array}{l}\text { He explained that the studies } \\
\text { indicate that temperatures and low } \\
\text { humidity increase the viability of } \\
\text { SARS-CoV- } 2 \text { in the droplets, and } \\
\text { that the virus can persist for } 3 \\
\text { hours in aerosols. }\end{array}$ & $\begin{array}{l}\text { They inform that } \\
\text { measures such as the use } \\
\text { of negative pressure } \\
\text { ventilation in the hospital } \\
\text { sectors, open space, use } \\
\text { of the face mask in } \\
\text { crowded areas, } \\
\text { disinfection of frequently } \\
\text { touched surfaces, } \\
\text { individual hygiene, such } \\
\text { as washing hands } \\
\text { regularly and avoiding } \\
\text { contact, are necessary to }\end{array}$ \\
\hline
\end{tabular}


Research, Society and Development, v. 10, n. 4, e44310414300, 2021

(CC BY 4.0) | ISSN 2525-3409 | DOI: http://dx.doi.org/10.33448/rsd-v10i4.14300

\begin{tabular}{|c|c|c|c|c|c|c|c|c|}
\hline & & & & & & & & $\begin{array}{l}\text { reduce the spread of } \\
\text { SARS-CoV-2 via aerosol. }\end{array}$ \\
\hline Article 10 & $\begin{array}{l}\text { Aerosol and } \\
\text { Surface } \\
\text { Distribution of } \\
\text { Severe Acute } \\
\text { Respiratory } \\
\text { Syndrome } \\
\text { Coronavirus } 2 \\
\text { in Hospital } \\
\text { Wards, } \\
\text { Wuhan, China, } \\
2020\end{array}$ & $\begin{array}{l}\text { Guo ZD, Wang ZI, } \\
\text { Zhang SF, Li X, Li } \\
\text { L, Li C, et al. (Guo } \\
\text { et al., 2020) }\end{array}$ & $\begin{array}{c}202 \\
0\end{array}$ & USA & $\begin{array}{l}\text { Testing surface and } \\
\text { air samples from an } \\
\text { Intensive Care Unit } \\
\text { (ICU) and a general } \\
\text { ward COVID-19 at } \\
\text { Huoshenshan } \\
\text { Hospital in Wuhan, } \\
\text { China }\end{array}$ & $\begin{array}{c}\text { Experimental } \\
\text { quantitative study }\end{array}$ & $\begin{array}{l}\text { It has been suggested that and the } \\
\text { transmission distance of the SARS- } \\
\text { CoV- } 2 \text { via aerosol can be } 4 \mathrm{~m} \text {. }\end{array}$ & $\begin{array}{l}\text { They concluded that } \\
\text { SARS-CoV- } 2 \text { is widely } \\
\text { distributed in the air and } \\
\text { on the surfaces of } \\
\text { objects, with the ICU } \\
\text { being the environment } \\
\text { most contaminated by } \\
\text { the virus. Implying a high } \\
\text { risk of infection for the } \\
\text { team and other close } \\
\text { contacts. Suggesting that } \\
\text { stricter protection } \\
\text { measures be taken by } \\
\text { the health team. }\end{array}$ \\
\hline
\end{tabular}

Source: Authors. 
Research, Society and Development, v. 10, n. 4, e44310414300, 2021

(CC BY 4.0) | ISSN 2525-3409 | DOI: http://dx.doi.org/10.33448/rsd-v10i4.14300

Table 2. Synthesis of the dispersion characteristics of aerosols with SARS-CoV-2. 2020.

\begin{tabular}{|c|c|c|c|c|c|c|c|}
\hline & Origin of aerosol & $\begin{array}{c}\text { Viral load } \\
\text { identified in the } \\
\text { air }\end{array}$ & $\begin{array}{l}\text { Aerosol particle } \\
\text { size with viral load }\end{array}$ & Dispersal & Dwell time in air & $\begin{array}{l}\text { Influence of } \\
\text { temperature }\end{array}$ & $\begin{array}{l}\text { Influence of relative } \\
\text { humidity }(\mathbf{R H})\end{array}$ \\
\hline $\begin{array}{l}\text { Article } \\
\quad 1\end{array}$ & $\begin{array}{l}\text { Laboratory sample generated by } \\
\text { disperser }\end{array}$ & $\begin{array}{l}10^{2.7} \text { TCID } 50 \text { per } \\
\text { liter of air * }\end{array}$ & $<5 \mu \mathrm{m}^{\mathrm{b}}$ & - & $3 \mathrm{~h}$ & - & - \\
\hline $\begin{array}{l}\text { Article } \\
\quad 2\end{array}$ & $\begin{array}{l}\text { Particles in suspension and } \\
\text { deposited in the environment }\end{array}$ & $\begin{array}{l}1.0 \text { to } 21.0 \\
\text { cópias } / \mathrm{m}^{3}\end{array}$ & $0.25 \mu \mathrm{m}^{\mathrm{b}}$ to $2.5 \mu \mathrm{m}^{\mathrm{b}}$ & $\begin{array}{l}2 \mathrm{~m} \text { with barrier and } \\
3 \mathrm{~m} \text { without barrier }\end{array}$ & - & - & - \\
\hline $\begin{array}{l}\text { Article } \\
\quad 3\end{array}$ & $\begin{array}{l}\text { Air samples taken in rooms and } \\
\text { corridors }\end{array}$ & $\begin{array}{c}\text { Average } \\
\text { concentration of } \\
2.59 \text { to } 2.86 \\
\text { copies/ liter of air }\end{array}$ & $\begin{array}{l}\text { The analyzed } \\
\text { particle size was not } \\
\text { reported but its } \\
\text { theoretical basis } \\
\text { was }<10 \mu \mathrm{m}\end{array}$ & - & $\begin{array}{l}\text { Reports that it } \\
\text { remains for a few } \\
\text { hours, however, this } \\
\text { value is not informed }\end{array}$ & - & - \\
\hline \multirow[t]{2}{*}{$\begin{array}{l}\text { Article } \\
\quad 4\end{array}$} & $\begin{array}{l}\text { Cough, spontaneous dyspneic } \\
\text { breathing. Procedures such as: } \\
\text { Aspiration; Laryngoscopy. } \\
\text { Non-invasive ventilation; } \\
\text { Nebulization; Bag-valve-mask } \\
\text { ventilation; } \\
\text { Bronchoscopy; Cardiopulmonary } \\
\text { resuscitation. And the use of } \\
\text { oxygen mask and } \\
\text { high flow nasal cannula. }\end{array}$ & - & $0.25 \mu \mathrm{m}^{\mathrm{b}}$ to $1 \mu \mathrm{m}^{\mathrm{b}}$ & Up to $8 \mathrm{~m}$ & $\mathrm{Up}$ to $3 \mathrm{~h}$ & $\begin{array}{l}\text { It shows that the } \\
\text { temperature } \\
\text { influences, but this } \\
\text { value is not informed }\end{array}$ & $\begin{array}{l}\text { Addresses that the RH } \\
\text { influences, but does not } \\
\text { inform the value }\end{array}$ \\
\hline & Cough, speak and sneeze & - & - & $\begin{array}{l}10 \text { meters indoors } \\
\text { and without the use }\end{array}$ & $\begin{array}{l}\text { Reports that the } \\
\text { particle can remain }\end{array}$ & $\begin{array}{l}\text { Temperature between } \\
0 \text { and } 5^{\circ} \mathrm{C} \text { makes the } \\
\text { virus more viable }\end{array}$ & $\begin{array}{l}\text { RH between } 90 \text { and } \\
100 \% \text { contribute to }\end{array}$ \\
\hline
\end{tabular}


Research, Society and Development, v. 10, n. 4, e44310414300, 2021

(CC BY 4.0) | ISSN 2525-3409 | DOI: http://dx.doi.org/10.33448/rsd-v10i4.14300

\begin{tabular}{|c|c|c|c|c|c|c|c|}
\hline $\begin{array}{l}\text { Article } \\
\quad 5\end{array}$ & & & & $\begin{array}{l}\text { of a mask; } 2 \mathrm{~m} \text { with } \\
\text { the use of a mask }\end{array}$ & $\begin{array}{l}\text { for hours, but this } \\
\text { value is not informed }\end{array}$ & & $\begin{array}{l}\text { viral stability and } \\
\text { spread }\end{array}$ \\
\hline $\begin{array}{l}\text { Article } \\
\quad 6\end{array}$ & Cough, speak and sneeze & - & $<5 \mu \mathrm{m}^{\mathrm{b}}$ & 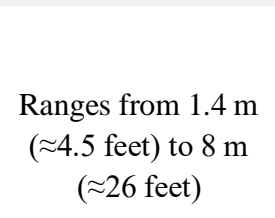 & $3 \mathrm{~h}$ & $\begin{array}{l}\text { It was shown that the } \\
\text { temperature } \\
\text { influences the viral } \\
\text { spread, but this value } \\
\text { is not informed }\end{array}$ & $\begin{array}{c}\text { Informs that RH } \\
\text { contributes to viral } \\
\text { dissemination, however } \\
\text { this value is not } \\
\text { exposed }\end{array}$ \\
\hline $\begin{array}{l}\text { Article } \\
\quad 7\end{array}$ & $\begin{array}{l}\text { Breathing, speaking, singing, } \\
\text { coughing and sneezing }\end{array}$ & - & $<1 \mu \mathrm{m}^{\mathrm{b}}$ & $\begin{array}{c}4 \text { meters to } 8.2 \mathrm{~m}(\approx \\
13 \text { to } 27 \text { feet })\end{array}$ & $3 \mathrm{~h}$ & $\begin{array}{l}\text { Points out that the } \\
\text { temperature } \\
\text { influences the } \\
\text { survival and spread of } \\
\text { the virus when } \\
\text { transported by air, but } \\
\text { this value is not } \\
\text { informed }\end{array}$ & $\begin{array}{l}\text { Informs that viruses } \\
\text { that have a lipid } \\
\text { envelope such as } \\
\text { SARS-CoV-2, have } \\
\text { better survival capacity } \\
\text { at low RH }(<50 \%) \text {. In } \\
\text { addition, RH has an } \\
\text { effect on viral spread }\end{array}$ \\
\hline $\begin{array}{l}\text { Article } \\
\quad 8\end{array}$ & Expiration & $\begin{array}{l}\text { Average } \\
\text { concentration of } \\
0.3 \text { ( } \log _{10} \text { virus } \\
\text { copies per } \\
\text { sample). }\end{array}$ & $\leq 5 \mu \mathrm{m}^{\mathrm{b}}$ & - & - & - & - \\
\hline $\begin{array}{l}\text { Article } \\
\quad 9\end{array}$ & Cough, speak and sneeze & - & - & - & $3 \mathrm{~h}$ & $\begin{array}{l}\text { It has been reported } \\
\text { that temperature can } \\
\text { influence the viability } \\
\text { of SARS-CoV in viral } \\
\text { particles, but such a } \\
\text { value is not reported. }\end{array}$ & $\begin{array}{l}\text { Mentions that low RH } \\
\text { may increase the } \\
\text { viability of SARS- } \\
\text { CoV-2 in viral particles }\end{array}$ \\
\hline $\begin{array}{l}\text { Article } \\
10\end{array}$ & Air samples from wards & - & - & $4 \mathrm{~m}$ & - & - & - \\
\hline
\end{tabular}

* Viable virus in aerosol expressed in 50\% infectious dose in tissue culture (TCID50) per liter of air. ** Copies of viral particles per microliter of the reaction. ${ }^{\mathrm{b}}$ Micrometer. Source: Authores. 


\section{Discussion}

The results showed important characteristics of SARS-CoV-2 aerosols dispersion, such as particle sizes smaller than $5 \mu \mathrm{m}$ from cough, sneezing, speech and breathing that reach distances higher than $2 \mathrm{~m}$ and stay in air three hours. Regarding the influence of relative air humidity and temperature on virus dispersion, the studies did not present consistent scientific evidence.

The Center of Diseases and Control (Centers for disease control and prevention, 2020a) and the World Health Organization (World Health Organization, 2020d) traditionally considered the concept of droplets and aerosols by particle size greater than or less than $5 \mu \mathrm{m}$, respectively and capable of reaching distances greater than or equal to one or two meters. Based on this concept, coughing, sneezing and speech were able to generate only droplets, being sedimented less than one meter away while aerosols were generated only in specific procedures.

The results showed important characteristics in the dispersion of aerosols containing SARS-CoV-2 in particles smaller than $5 \mu \mathrm{m}$ from coughing, sneezing, speech and breathing (A1, A4-9). In the study of Liu et al. (Liu et al., 2020) the droplet size distributions of the airborne SARS-CoV-2 were investigated by measuring viral RNA in aerosols in two different hospitals in Wuhan. The findings showed that the Aerosols of SARS-CoV-2 included mainly two size intervals, one in the sub micrometer region $(\mathrm{dp} 0.25-1.0 \mu \mathrm{m})$ and the other in the super-micrometer region $(\mathrm{SD}>2.5 \mu \mathrm{m})$, collected in different locations from the ICU to the medical rest room 17.

Regarding the dispersion of aerosol particles, it was identified in six studies (A2, A4, A5, A6, A7 and A10) that the dispersion occurred from 1.4 to $10.0 \mathrm{~m}$ away from the source of the source. A recent study inferred that aerosol particles released in a sneeze can form a cloud of turbulent gas and reach 7 to $8 \mathrm{~m}$ (Bourouiba, 2020). This finding converges with the assumptions pointed out by review articles A4, A6 and A7 17,19,20 (Liu et al., 2020; Setti et al., 2020; Wilson et al., 2020).

In a recent publication, WHO (World Health Organization, 2020f) recognized the transmission of the new coronavirus via aerosol from different sources, not only in specific procedures as previously adopted, especially indoors, updating its guidelines. However, the CDC continues to consider in its guideline the transmission route by aerosols of the SARS-CoV-2 only in aerosol-generating procedures (Centers for disease control and prevention, 2020b). Doubts about the aerial transmission of SARS-CoV-2 persist and the indication of further research that can better understand the behavior of droplet and aerosol in different environmental scenarios, especially indoors, are necessary (Fennelly, 2020; Tang et al., 2020).

The results also showed that the least analyzed characteristic was the time of permanence of the new coronavirus in the air. One study points out that coronaviruses can survive for long periods in aerosols (Otter et al., 2016), such as human coronavirus 229E (HCoV-229E), which can remain viable for up to 6 days 31(Ijaz, Brunner, Sattar, Nair, \& Johnson-Lussenburg, 1985). Article 1 was the only one to test this variable, inferring a value of $3 \mathrm{~h}$ of SARS-CoV-2 in the air (Doremalen et al., 2020). This study was the most used reference by the other papers regarding the time of permanence. However, this article used a disperser to generate the aerosols. Thus, there is no way to determine the reliance of this value is, since the disperser does not reflect a clinical scenario in which aerosols are generated by infected individuals (World Health Organization, 2020d).

The analyzed studies presented different measurement unit parameters to identify the viral load, which made it difficult to compare them. In the study by Liu et al. (Liu et al., 2020) the concentration of the new coronavirus (SARS-CoV-2) in aerosol particles was identified between the range of 1 to 21 copies $/ \mathrm{m} 3$, and the sites with the highest concentrations were the toilets of the infected patients (19 copies $/ \mathrm{m} 3)$, male staff change room (20 copies $/ \mathrm{m} 3)$, the warehouse (21 copies $/ \mathrm{m} 3)$. The authors emphasized that the sites that had a negative pressure system, as well as strict hygiene of the environment, presented extremely low or undetectable concentration rates. It is highly emphasized the importance of the professional who provided assistance to the patient with COVID-19 not to remove the mask at the place of remove PPEs, since the contamination of the air in the staff change room was high.

The influence of air temperature and relative humidity $(\mathrm{RH})$ on the transmission process of the new coronavirus was 
highlighted in five studies (A4, A5, A6, A7 and A9) and low air temperatures and humidity increase the transmission viability of SARS-CoV-2. Article 5 estimates a temperature between 0 and $5^{\circ} \mathrm{C}$ as the most favorable for viral dispersion (Santarpia et al., 2020). A study aimed to evaluate if the climate is capable to limit the coronavirus dispersion. It was found that positive cases were present between $-3.44^{\circ} \mathrm{C}$ to $12.55^{\circ} \mathrm{C}$, with the average value of $5.81^{\circ} \mathrm{C}$ (Araújo \& Naimi, 2020). Regarding air humidity, article 5 states that a high relative humidity is favorable to the virus dissemination, while article 7 assumes that low relative humidity is more conducive to coronavirus propagation (Anderson et al., 2020; Setti et al., 2020). A recent study supports that low relative humidity is capable of affecting the transmissibility of respiratory viruses, increasing the time of viral dispersion in the air. On the other hand, it should be considered that the population density and the host behavior are factors that can also influence viral dispersion, in addition to climate. In the world scenario, we observed that in the different types of climate and relative humidity, cases of COVID-19 are present (Araújo \& Naimi, 2020).

However, it is necessary to report the need for new primary studies consistent with rigorous methodologies for evaluating the dispersion of SARS-CoV-2 in the indoor air considering the different variables, such as source origin, particle size and distance traveled. And if possible that they are carried out in a real clinical environment, respecting all rigor and ethical principles.

\section{Conclusion and Remarks}

The aerosol particles with SARS-CoV-2 may have an infectious viral load, presenting a minimum size of up to 0.25 $\mu \mathrm{m}$, being able to reach up to $10 \mathrm{~m}$ distance after being released by an infected person during some expiratory process. These aerosols can survive in the air for some hours, studies have pointed out up to 3 hours of air stay, such information is limited by the fact that aerosols have been generated by a disperser and may not be compatible with the reality of the transmission process.

Although some studies have stated that temperature and relative humidity influence the SARS-CoV-2 aerosols dispersion, it was not presented scientific consistency to prove this statement. Moreover, there is no way to affirm that low temperatures and low RH are limiting characteristics or that favor viral dispersion, since there are other factors that influence the spread of SARS-CoV-2 in countries with higher temperatures and RH.

In general, it is notorious the divergence of information regarding certain characteristics of aerosol dispersion, that may be associated with the recent coronavirus dissemination, with few primary studies and some methodological limitations. The use of concepts traditionally acceptable and applied by many health agencies regarding the route of transmission by aerosols and droplets, may need to be reviewed as scientific evidence advances, such as coughing, and sneezing produce only droplets that are deposited before reaching a distance of 1 to $2 \mathrm{~m}$. Thus, according to our finding further studies focusing on the dispersion of SARS-CoV-2 aerosols in the indoor air are necessary, there is a lack of information in this area. So we suggest that more deep and conclusive researches should be conducted.

\section{Acknowledgment}

The authors thank to Coordination of Superior Level Staff Improvement (CAPES/Brazil), National Council for Scientific and Technological Development (CNPq/Brazil) and Alagoas State Research Support Foundation (FAPEAL/Brazil). The findings achieved herein are solely the responsibility of the authors.

\section{References}

Anderson, E. L., Turnham, P., Griffin, J. R., \& Clarke, C. C. (2020). Consideration of the Aerosol Transmission for COVID-19 and Public Health. Risk Analysis, 40(5), 902-907. https://doi.org/10.1111/risa.13500 
Araújo, M., \& Naimi, B. (2020). Spread of SARS-CoV-2 Coronavirus likely constrained by climate. MedRixv, 1-26. https://doi.org/10.1101/2020.03.12.20034728

Asadi, S., Bouvier, N., Wexler, A. S., \& Ristenpart, W. D. (2020). The coronavirus pandemic and aerosols: Does COVID-19 transmit via expiratory particles? Aerosol Science and Technology, 54(6), 635-638. https://doi.org/10.1080/02786826.2020.1749229

Bahl, P., Doolan, C., de Silva, C., Chughtai, A. A., Bourouiba, L., \& MacIntyre, C. R. (2020). Airborne or Droplet Precautions for Health Workers Treating Coronavirus Disease 2019? The Journal of Infectious Diseases, 1-8. https://doi.org/10.1093/infdis/jiaa189

Bourouiba, L. (2020). Turbulent Gas Clouds and Respiratory Pathogen Emissions: Potential Implications for Reducing Transmission of COVID-19. JAMA Journal of the American Medical Association, 323(18), 1837-1838. https://doi.org/10.1001/jama.2020.4756

Centers for disease control and prevention. (2020a). How COVID-19 Spreads. Retrieved from https://www.cdc.gov/coronavirus/2019ncov/transmission/index.html

Centers for Disease Control and prevention. (2020b). Interim Infection Prevention and Control Recommendations for Patients with Suspected or Confirmed Coronavirus Disease 2019 (COVID-19) in Healthcare Settings. Retrieved from https://www.cdc.gov/coronavirus/2019-ncov/hcp/disposition-hospitalizedpatients.html

Chen, J. (2020). Pathogenicity and transmissibility of 2019-nCoV-A quick overview and comparison with other emerging viruses. Microbes and Infection, 22(2), 69-71. https://doi.org/10.1016/j.micinf.2020.01.004

Doremalen, N. van, Bushmaker, T., Morris, D. H., Holbrook, M. G., Gamble, A., Williamson, B. N., \& Munster, V. J. (2020). Aerosol and Surface Stability of SARS-CoV-2 as Compared with SARS-CoV-1. The New England Journal of Medicine, 382(16), 0-3. https://doi.org/10.1056/NEJMc2004973.

Fathizadeh, H., Maroufi, P., Momen-Heravi, M., Dao, S., Köse, S., Ganbarov, K., \& Kafil, H. S. (2020). Protection and disinfection policies against SARSCoV-2 (COVID-19). Le Inferziono in Medicina, 2, 185-191.

Fennelly, K. P. (2020). Particle sizes of infectious aerosols: implications for infection control. The Lancet Respiratory Medicine, 8(9), 914-924. https://doi.org/10.1016/S2213-2600(20)30323-4

Guo, Z.-D., Wang, Z.-Y., Zhang, S.-F., Li, X., Lin Li, Li, C., \& Chen, W. (2020). Surface distribution of severe acute respiratory syndrome coronavirus 2 in Leishenshan Hospital in China. Indoor and Built Environment, 26(7). https://doi.org/10.1177/1420326X20942938

Ijaz, M. K., Brunner, A. H., Sattar, S. A., Nair, R. C., \& Johnson-Lussenburg, C. M. (1985). Survival characteristics of airborne human coronavirus 229E. Journal of General Virology, 66(12), 2743-2748. https://doi.org/10.1099/0022-1317-66-12-2743

Leung, N. H. L., Chu, D. K. W., Shiu, E. Y. C., Chan, K. H., McDevitt, J. J., Hau, B. J. P., \& Cowling, B. J. (2020). Respiratory virus shedding in exhaled breath and efficacy of face masks. Nature Medicine, 26(5), 676-680. https://doi.org/10.1038/s41591-020-0843-2

Liu, Y., Ning, Z., Chen, Y., Guo, M., Liu, Y., Gali, N. K., \& Lan, K. (2020). Aerodynamic analysis of SARS-CoV-2 in two Wuhan hospitals. Nature, 582(7813), 557-560. https://doi.org/10.1038/s41586-020-2271-3

McGowan, J., Sampson, M., Salzwedel, D. M., Cogo, E., Foerster, V., \& Lefebvre, C. (2016). PRESS Peer Review of Electronic Search Strategies: 2015 Guideline Statement. Journal of Clinical Epidemiology, 75, 40-46. https://doi.org/10.1016/j.jclinepi.2016.01.021

Morawska, L., \& Cao, J. (2020). Airborne transmission of SARS-CoV-2: The world should face the reality. Environment International, 139(April), 105730. https://doi.org/10.1016/j.envint.2020.105730

Otter, J. A., Donskey, C., Yezli, S., Douthwaite, S., Goldenberg, S. D., \& Weber, D. J. (2016). Transmission of SARS and MERS coronaviru ses and influenza virus in healthcare settings: The possible role of dry surface contamination. Journal of Hospital Infection, 92(3), 235-250. https://doi.org/10.1016/j.jhin.2015.08.027

Peng, X., Xu, X., Li, Y., Cheng, L., Zhou, X., \& Ren, B. (2020). Transmission routes of 2019-nCoV and controls in dental practice. International Journal of Oral Science, 12(1), 1-6. https://doi.org/10.1038/s41368-020-0075-9

Peters, M. D., Godfrey, C., McInerney, P., Munn, Z., Tricco, A. C., \& Khalil, H. (2020). Chapter 11: Scoping reviews. In E. Aromataris \& Z. Munn (Eds.), JBI Manual for Evidence Synthesis. JBI. https://doi.org/https://doi.org/10.46658/JBIMES-20-12

PRISMA. (2015). Principais itens para relatar Revisões sistemáticas e Meta-análises: A recomendação PRISMA. Epidemiologia e Serviços de Saúde (Vol. 24). https://doi.org/10.5123/s1679-49742015000200017

Santarpia, J., Rivera, D., Herrera, V., Morwitzer, M. J., Creager, H., Santarpia, G., \& Lowe, J. (2020). Transmission Potential of SARS-CoV-2 in Viral Shedding Observed at the University of Nebraska Medical Center. MedRxiv, 1-12. https://doi.org/10.1101/2020.03.23.20039446

Setti, L., Passarini, F., De Gennaro, G., Barbieri, P., Perrone, M. G., Borelli, M., ... Miani, A. (2020). Airborne transmission route of covid-19: Why 2 meters/6 feet of inter-personal distance could not be enough. International Journal of Environmental Research and Public Health, 17(8). https://doi.org/10.3390/ijerph17082932

Tang, S., Mao, Y., Jones, R. M., Tan, Q., Ji, J. S., Li, N., \& Macintyre, C. R. (2020). Aerosol transmission of SARS-CoV-2? Evidence, prevention and control. Environment International Journal, 144. 1060039. https://doi.org/10.1016/j.envint.2020.106039

Wilson, N. M., Norton, A., Young, F. P., \& Collins, D. W. (2020). Airborne transmission of severe acute respiratory syndrome coronavirus-2 to healthcare workers: a narrative review. Anaesthesia, 75(8), 1086-1095. https://doi.org/10.1111/anae.15093

World Health Organization. (2020a). Coronavirus disease (COVID-19) advice for the public: Mythbusters. https://www.who.int/emergencies/diseases/novelcoronavirus-2019/advice-for-public/myth-busters 
Research, Society and Development, v. 10, n. 4, e44310414300, 2021

(CC BY 4.0) | ISSN 2525-3409 | DOI: http://dx.doi.org/10.33448/rsd-v10i4.14300

World Health Organization. (2020b). Coronavirus disease (COVID-19) advice for the public. https://pesquisa.bvsalud.org/portal/resource/pt/lis-47042

World Health Organization. (2020c). Infection prevention and control during health care when COVID-19 is suspected: interim guidance. https://apps.who.int/iris/handle/10665/331495

World Health Organization. (2020d). Modes of transmission of virus causing COVID-19: implications for IPC precaution recommendations: Scientific brief, 27 March. from https://apps.who.int/iris/handle/10665/331601?locale-attribute=pt\&

World Health Organization. (2020e). Naming the coronavirus disease (COVID-19) and the virus that causes it. https://www.who.int/emergencies/diseases/novelcoronavirus-2019/technical-guidance/naming-the-coronavirus-disease-(covid-2019)-and-the-virus-that-causes-it

World Health Organization. (2020f). Q\&A on coronaviruses (COVID-19): Is COVID-19 airborne? https://www.who.int/news-room/q-a-detail/coronavirusdisease-covid-19-how-is-it-transmitted 